\title{
¿
}

Алексеева Д.И.

\section{СОСТАВ И ПРОИСХОЖДЕНИЕ ВОТЧИН КНЯЗЯ ВАСИЛИЯ ЛУКИЧА ДОЛГОРУКОВА}

Аннотация: Предмет работь - изучение проблем светского землевладения в эпоху двориовых переворотов на основе делопроизводственных материалов, возникиих в прочессе конфискачии имущества «государственных преступников». Основньлм источником являются отписные книги, которые на данныймомент изучены недостаточно. Отписные книги представляют собой комплекс описаний, в данном случае составленных на имущество одного лища, и являются сложным и неоднородным источником.Для того, чтобы показать их иенность как исторического источника в статье в качестве одного из аспектов интерпретации рассматривается вопрос о землевладении крупного сановника князя Василия Лукича Долгорукова. Реконструкиия состава земель включает в себя сведения о составе и происхождении вотчин в Алатырском, Касимовском, Керенском, Кинишемском, Козельском, Копорском, Кромском, Курском, Лебедянском, Московском, Оболенском, Рузском уездах.С привлечением иньх материалов конфискации имущества уточнено происхождение вотчин. 10 вотчин были получены князем В.Л. Долгоруковым в результате сделки покупки или обмена, 11 вотчин было получено от родственников и всего 1 одна вотчина пожалована за службу. История формирования состава вотчин позволяет скорректировать некоторые неяснье моменты биографии князя - брак и иные родственные связи.Формирование крупного земельного комплекса связывается с карьерной и семейной историей князя В.Л. Долгорукова, а такэе с землевладением князей Долгоруковых в ХVII и начале ХVIII в. Review: The purpose of the research article is to study the problems of secular land ownership in the days of palace revolutions. The author of the article studies the documents of management and records keeping that were created in the process of seizing property of criminals who committed crime against the state. The main reference of the research is the so called registers of signed off property. At the present moment these registers are not sufficiently studied. Registers of signed property consist of a series of descriptions, particularly on property belonging to one physical entity. These registers are quite complex references containing all kinds of data. To show their importance as the primary source, the author of the article analyzes documents about land property that belonged to a famous nobleman Vasily Lukich Dolgorukov. The author touches upon the structure and origin of Dolgorukov's votchinas in Alatyr, Kasimovsky, Kerensky, Kinishemsky, Kozelsky, Koporsky, Kromsky, Kursk, Lebedyansk, Moscow, Obolensk and Ruszky Districts. By analyzing other documents about seized properties, the author of the article clarifies the origin of those votchinas. For example, Vitaly Lukich Dolgorukov obtained 10 votchinas as a result of purchase or exchange, 11 votchinas were inherited or received from relatives in any other way and only 1 votchina was actually given for good service. The analysis of the process of formation of votchinas allows to clarify some uncertain moments in Dolgorukov's biography such as his marriage and other close relations. The process of formation of such a large piece of land property is associated with Vitaly Lukich Dolgorukov's career and family history as well as the property that belonged to the Dolgorukovs in XVIIth and early XVIIIth centuries.

Ключевые слова: история, источниковедение, аграрная история, эпоха двориовьх переворотов, светское феодальное землевладение, отписнье книги, Василий Лукич Долгоруков, ХИІІ век, государственньле преступления, канцелярия конфискации. Keywords: history, source studies, agrarian history, the epoch of palace revolutions, secular feudal tenures, register of signed off property, Vasily Lukich Dolgorukov, XVIII century, crime against the state, administrative office for seized property.

И стория светского землевладения второй четверти XVIII в. по сравнению с предыдущими периодами мало освещены в историографии. Одним из первых обратил внимание на эволюционные процессы в землевладении крупных вотчинников С. В. Рождественский ${ }^{1}$. Состав вотчин Б. П. Шереметева рассмотрел

${ }^{1}$ Рождественский С. В. Служилое землевладение в Московском государстве. СПб., 1897. 
А. И. Заозерский ${ }^{2}$ В советское время проблемой формирования крупной светской вотчины занимались А. А. Новосельский ${ }^{3}$, С. М. Троицкий ${ }^{4}$ Я. Е. Водарский на основе переписных и ландратских книг определил состав имений многовотчинных земельных магнатов: Голицыных, Куракиных, Одоевских ${ }^{5}$. Существенный вклад в изучение процессов формирования вотчин, состава землевладельцев, происхождения вотчинных земель внесли работы О. А. Шватченко ${ }^{6}$.

Изучение светского землевладения, как правило, основывалось на анализе писцовых, переписных, ландратских книг, личных архивов. Для второй четверти XVIII в. есть возможность привлечь делопроизводственные и кадастровые документы, возникавшие в процессе конфискации имений. К. В. Сивков в единственной на сегодня работе по источниковедению отписных книг указывал, что этот источник является незаменимым для изучения помещичьего и крестьянского землевладения XVIII в. ${ }^{7}$ Между тем источники, возникшие в ходе конфискации, привлекались к изучению истории землевладения лишь в единичных случаях.

Состав и происхождение вотчин М. Г. Головкина на основе делопроизводственных материалов, связанных с процессом конфискации, исследова-

2 Заозерский А. И. Фельдмаршал Б. П. Шереметев. М., 1989.

${ }^{3}$ Новосельский A. А. Вотчинник и его хозяйство в XVII в. М.; Л., 1929.

${ }^{4}$ Троицкий С. М. Районирование форм феодальной ренты в крупной вотчине России в первой четверти XVIII в. // Ежегодник по аграрной истории Восточной Европы. 1968. Л., 1972. С. 115-126; Он же. Хозяйство крупного сановника России в первой четверти XVIII в. // Россия в период реформ Петра I. М., 1973.

${ }^{5}$ Водарский Я. Е. Население России в конце XVII - начале XVIII в. M., 1977; Он же. Дворянское землевладение XVII первой половине XVIII в. М., 1988.

${ }^{6}$ Шватченко О. А. Вотчинное землевладение в России в конце XVI века. M., 2008; Он же. Светские феодальные вотчины России в первой трети XVII века. М., 1990; Он же. Светские феодальные вотчины России во второй половине XVII в. М., 1996; Он же. Эволюция светских феодальных вотчин в России в конце XVI - начале XVIII в. Автореферат диссертации на соискание ученой степени доктора исторических наук. М., 1997; Он же. Светские феодальные вотчины России в эпоху Петра I. М., 2002.

${ }^{7}$ Сивков К. В. Отписные книги начала XVIII в. как исторический источник // Проблемы источниковедения. М., 1940. C. 367-390. ла П. К. Алефиренко. В качестве основного источника она использовала ведомость, составленную в Канцелярии конфискации в ходе работы «Комиссии по описи пожитков и деревень и разобрании долгов Остермана, Головкина с товарищами» ${ }^{8}$. На ее основе автор сделала вывод о состоянии вотчины Головкина, о земельной политике государства по отношению к влиятельным сановникам в конце Аннинского правления.

Вопросы происхождения тех или иных земель в составе крупных вотчин, попавших в дворцовое хозяйство в первой половине XVIII в., изучались Е. И. Индовой 9 . Она привлекла материалы Дворцового архива, в том числе и отдельные делопроизводственные материалы конфискационных. Е. И. Индова сделала вывод о соотношении земельных пожалований и конфискаций, на его основе прослеживается и экономический интерес государства в конфискации недвижимого имения у крупных землевладельцев.

В данной статье предполагается представить ценность документов, создававшихся в процессе конфискации вотчин, для изучения светского землевладения в эпоху дворцовых переворотов. Имущество подвергалось конфискации по разным причинам - за недоимки (часть материалов Канцелярии конфискации составляют документы Доимочной конторы), за срыв подрядов, наконец - в качестве репрессивной меры по политическим причинам. Источники, создававшиеся в ходе процесса конфискации, многообразны, однако наиболее информативными представляются отписные книги, составленные на имения крупных землевладельцев. В качестве одного из возможных аспектов интерпретации отписных книг предлагается реконструировать состав и происхождение вотчин князя В. Л. Долгорукова. Для того, чтобы максимально полно представить историю формирования вотчины, представляется необходимым соотнести изменения в составе вотчин Долгорукова с его личной и служебной биографией, а также с биографичми его родственников.

Князь Василий Лукич Долгоруков (ок. 1680$1739)$ - дипломат, действительный тайный совет-

${ }^{8}$ Алефиренко П. К. Отписная ведомость Канцелярии конфискации как источник по истории помещичьего землевладения // Вопросы социально-экономической истории и источниковедения периода феодализма в России Сб. ст. 70-летию А. А. Новосельского / отв. ред. Н. В. Устюгов. М., 1961. C. 307-309.

${ }^{9}$ Индова Е. И. Дворцовое хозяйство в России (первая половина XVIII века). М., 1964. 


\section{Политика и общество 2 (110) • 2014}

ник, член Верховного тайного совета, участник дворцового переворота 1730 г. После восстановления самодержавия (25 февраля 1730) вместе со своей семьей В. Л. Долгоруков подвергся опале. Вначале он был определен губернатором в Сибирь, но по дороге взят «под крепкий караул», а затем последовал указ о лишении чинов и конфискации имущества самого В. Л. Долгорукова и его родственников. Для описания, учета и «отписки на государыню» имущества опальных была создана особая «Комиссия по описи пожитков князей Долгоруковых».

Дела Комиссии сохранились в фонде Дворцового архива РГАДА и насчитывают 10 единиц хранения ${ }^{10}$. Еще 22 дела Комиссии сохранилось в фонде «Уголовные дела по государственным преступлениям»; они содержат не только материалы о конфискации, но и следственные документы ${ }^{11}$.

В состав дел входят делопроизводственные документы: описи, ведомости, реестры конфискованного имущества, доношения и т. д. Конфискации подвергалась не только недвижимость, абсолютно все: ученические тетрадки, одежда, обувь, посуда, «курьезные вещи». Отправлявшимся в ссылку Долгоруковым было разрешено оставить при себе только нательные кресты и обручальные кольца ${ }^{12}$.

Процесс конфискации недвижимого имения описал К. В. Сивков в единственной существующей на данный момент работе по источниковедению отписных книг ${ }^{13}$. Делопроизводство Комиссии описи пожитков князей Долгоруковых имело некоторые особенности. Как и было отмечено исследователем, в Вотчинной коллегии вначале составлялись справки об имениях каждого из опальных. Далее следовал процесс описания на местах, который проводился провинциальными канцеляриями или специально присланными для этого чиновниками. К процедуре, описанной К. В. Сивковым, следует добавить, что по итогам описания и сбора отписных книг из различных провинци-

\footnotetext{
${ }^{10}$ РГАДА. Ф. 1239. Оп. 2. Д. 1731-1740.

${ }^{11}$ Там же. Ф. 6. Оп. 1. Д. 164-185; Черникова Т. В. «Государево слово и дело» во времена Анны Иоанновны. // История CССР. 1989. № 5. С. 157.

${ }^{12}$ Курукин И. В. Повседневная жизнь Тайной канцелярии. M., 2008. С. 557.

${ }^{13}$ Сивков К. В. Отписные книги начала XVIII века как исторический источник // Проблемы источниковедения / под. ред. С. Н. Валка. М.-Л., 1940. С. 369-390.
}

альных канцелярий составлялась общая табличная ведомость, куда вносились сведения о землевладении каждого лица по всем уездам. С ее помощбю сопоставлялись сведения Вотчинной коллегии с поданными отписными книгами. Такая «Ведомость о недвижимых имениях» князя В. Л. Долгорукова сохранилась в фонде Поместного приказа ${ }^{14}$. Она имеет табличную форму, в три колонки. В первой помещены сведения о происхождении конкретного имения по данным Вотчинной коллегии, в третьей - по отписным книгам, а в самую узкую колонку по центру вписывалось количество земли в четвертях ${ }^{15}$.

В фонде Вотчинной коллегии хранятся три объемных тома отписных книг на имения князей Долгоруковых. Они сшиты из отдельных тетрадей, написаны разными писцами, по-видимому, на месте, в самом отписываемом имении ${ }^{16}$. В составе этих томов содержится 11 отписных книг на имения князя В. Л. Долгорукова.

В качестве дополнительного источника для реконструкции состава вотчин использовался реестр бумаг, изъятых из дома В. Л. Долгорукова ${ }^{17}$. Этот реестр составлен на бумаги, касающиеся сведений о землевладении, он сгруппирован по географическому принципу и представляет собой краткие недатированные заголовки дел.

Реконструкция выполнена поуездно, уезды выстроены в хронологическом порядке по мере приобретения В. Л. Долгоруковым, внутри одного уезда также выдержан хронологический принцип.

В Кинешемском уезде на 16 августа 1730 г. В. Л. Долгоруков владел деревней Прислонихой с прилежащими деревнями ${ }^{18}$. Земельный комплекс в Кинешемском уезде складывался постепенно. Согласно Ведомости, в 1684 г. В.Л. Долгоруков купил у С. С. Вельяминовой 15 четвертей в деревне Хоромне, однако в отписных книгах на земли Кинешемского уезда этой деревни не значится. В 1697 г. князь приобрел еще одну вотчину - пустошь Когряту в Вичужской волости (26 четвертей). А в 1714 г. В. Л. Долгоруков получил «родовой вотчины деда ево» деревню Прислониху

\footnotetext{
${ }^{14}$ РГАДА. Ф. 1209. ОП. 4. Д. 5419. Л. 79-89.

${ }^{15}$ Там же.

${ }^{16}$ РГАДА. Ф. 1209. Оп. 4. Д. 5419. Д. 5431. Д. 5430.

${ }^{17}$ Там же. Ф. 1239. Оп. 2. Д. 1734. Л. 356-377 об.

${ }^{18}$ Там же. Ф. 1209. Оп. 4. Д. 5431. Л. 527-533. В настоящее время д. Прислониха расположена в Вичугском районе Ивановской области.
} 
с деревнями и пустошами ${ }^{19}$. В отписных книгах на эти земли, вопреки обыкновению, не значится количество четвертей земли. Примечательно также, что этот земельный комплекс в составе вотчин князя В. Л. Долгорукова формировался в течение длительного срока, а самый крупный надел принадлежал его деду и достался, по сути, в наследство. Таким образом, В. Л. Долгоруков сознательно покупал небольшие земельные наделы в Вичужской волости, прежде чем получил самый крупный участок земли в наследство.

Стоит отметить, что в 1714 г. В. Л. Долгоруков получил еще одно имение - село Ивино в Московском уезде. Оба надела значатся в «ведомости» с общей формулировкой «вотчина деда ево». Так как дед со стороны отца окольничий Ф. Ф. Долгоруков умер в 1664 г., то речь должна идти о деде со стороны матери. Матерью Василия и Александра Лукичей Долгоруковых была Анна Ивановна Желябужская, первая жена Луки Федоровича Долгорукова. Анна Ивановна - дочь думного дворянина Ивана Афанасьевича Желябужского, который дал своей дочери в приданное деревню Прислониху Кинишемского уезда и село Ивино Московского уезда. Однако, почему эти земли отошли к В. Л. Долгорукову именно в 1714 г., не ясно ${ }^{20}$. Анна вышла замуж за Л. Ф. Долгорукова в 1676 г., а умерла до 1682 г. - в этот год состоялось вторая женитьба Л. Ф. Долгорукова на А. В. Философовой. До сих пор не было известно, когда именно умер И. А. Желябужский, известный дипломат и мемуарист. Обычно называется дата - после 1709 г. (год окончания его записей) $^{21}$. Таким образом, можно предположить, что он умер к 1714 г., когда его вотчины и перешли к внуку. Но если Желябужский дал эти имения в приданное за дочерью в 1676 г., то как они могли оказаться у него к 1714 г.? Возможно, деревня Прислониха и село Ивино делились по долям между разными собственниками. Часть этих земель могла отойти в приданное, а вторая часть остаться во владении Желябужского. Сведений, подтверждающих это предположение, впрочем, найдено не было-во время валового писцового описания в 1678 г. эти земли за Желябужским не значат-

${ }^{19}$ РГАДА. Ф. 1209. Оп. 4. Д. 5419. Л. 80.

${ }^{20}$ Власьев Г. А. Потомство Рюрика: Материалы для составления родословий. СПб., 1907. Т. 1. Князья Черниговские. Ч. 3. C. 39.

${ }^{21}$ Богданов А. П., Каган М. Д. Желябужский Иван // Словарь книжников и книжности древней Руси. XVII в. СПб., 1992. Вып. 3. Ч. 1. С. 322-326. $\mathrm{cя}^{22}$. Деревней Прислонихой и Московского уезда сельцом Ульяновым (Ивиным) в 1678 г. владел Л. Ф. Долгоруков $^{23}$. А во время описаний 1705 и 1711 г. (т.е. еще до 1714 г.) В. Л. Долгоруков владел Московского уезда Замыцкого стана селом «Улином, Ивином тож» ${ }^{24}$.

Отписная книга на вотчины Алатырского уезда выявлена не была. Однако, в Ведомости сказано, что Алатырского уезда село Иванково в 1700 г. перешло к Василию Лукичу от его отца. Более того, в этом же документе упоминается отписная книга, составленная на эти земли ${ }^{25}$. В реестре бумаг на вотчины В. Л. Долгорукова также содержатся упоминания бумаг на это село ${ }^{26}$. Принадлежность этого имения Долгорукову отмечала Е. И. Индова. Анализируя состав дворцовых владений в XVIII в., она указала, что расширение дворцовых земель происходило, в том числе, и за счет конфискованного имущества. На основе материалов Дворцового архива РГАДА Индова составила таблицу приписанных ко дворцовым земель, среди которых упоминается и село Иванково, отписанное у В. Л. Долгорукова ${ }^{27}$.

27 августа 1730 г. было описано имение в Козельском уезде в Подгородском стане, село Ерлыково с деревнями ${ }^{28}$. История с Козельскими землями В. Л. Долгорукова довольно запутана. Отписная книга на них была составлена в августе 1730 г. В декабре этого же года в Дворцовый отдел была подана справка из Вотчинной коллегии о количестве земель (в отписной не было сведений о четвертной пашне $)^{29}$. При этом сведения о количестве пашенной земли в Ведомости, составленной по результатам отписки, и в справке, поданные в Дворцовый отдел, отличаются. В Ведомости записано, что на село Славышино с деревнями приходится 263 четверти. А в справке, посланной в Дворцовый отдел спустя четыре месяца, в селе Славышине значи-

22 Шватченко О. А. Светские феодальные вотчины в России во второй половине XVII века (историко-географический очерк). М., 1996. С. 176.

${ }^{23}$ Там же. С. 91.

${ }^{24} \mathrm{OH}$ же. Светские феодальные вотчины в эпоху Петра I. М., 2002. C. 149.

${ }^{25}$ РГАДА. Ф. 1209. Оп. 4. Д. 5419. Л. 82.

${ }^{26}$ Там же. Ф. 1239. Оп. 2. Д. 1734. Л. 372.

${ }^{27}$ Индова Е. И. Дворцовое хозяйство... С. 59.

${ }^{28}$ РГАДА. Ф. 1209. Оп. 4. Д. 5431. Л. 240-254 об. Ныне пос. Ярлыково Козельского района Калужской области.

${ }^{29}$ РГАДА. Ф. 1239. Оп. 3. Д. 35418. Л. 1-4. 


\section{Политика и общество 2 (110) • 2014}

лось 265 четвертей, а всего, включая прилегающие деревни, вотчина составляла 365 четвертей без полуосмины и без получетверика. Таким образом, в период с октября (с момента подачи отписной книги, созданной в августе) к декабрю 1730 г. размер владения расширился, но повторного описания земель не производилось.

В 1697 г. В. Л. Долгоруков получил «родовую вотчину деда ево» «треть села Славышина да село Кудринское, Лавровское тож, да в селе Ерлыкове 3 деревнею да пустошь 3 жеребьями и пустошами». По писцовым книгам в 1678 г. этими землями владел его дед по материнской линии И. А. Желябужский ${ }^{30}$.

В 1704 г. В. Л. Долгоруков купил у Якова Хрущева жребий в селе Гришинском в полосмины. А в 1705 г. его сестра А. Л. Стрешнева «поступилась» ему 50 четвертей в деревне Гришинской. Однако, старосты местных деревень показали, что все эти земли были записаны за Александром Лукичом Долгоруковым (ум. 1724), а не за его братом. В Вотчинной коллегии справились в переписных книгах 1710 г. и выяснили, что души мужского пола действительно были записаны за А. Л. Долгоруковым. По сводной Ведомости и по дополнительной, отосланной в Дворцовый отдел, обозначено, что дело «следуеца», т.е. в декабре 1730 г. (то есть уже после приписки к Дворцовому ведомству, состоявшейся осенью 1730) этот вопрос еще не был до конца разрешен.

Вероятнее всего, эти земли все-таки действительно принадлежали А. Л. Долгорукову. Г. А. Власьев упоминает, что село Славытино и Кудринское после смерти А. Л. Долгорукова в 1724 г. велено было справить за его женой княгиней Авдотьей ${ }^{31}$.

29 августа 1730 г. были отписаны земли в Лебедянском уезде в Городском стане в селе Спасском. ${ }^{32}$ В 1704 г. В. Л. Долгоруков выменял у Максима Кузьмина 10 четвертей села Парое. А село Спасское получил от дяди Я. Ф. Долгорукова в 1705 г., о чем имеется запись в отказных книгах. Эти сведения указаны как в общей справке, так и самой отписной книге.

\footnotetext{
${ }^{30}$ Шватченко О. А. Светские феодальные вотчины в России во второй половине XVII в. (историко-географический очерк) М., 1996. С. 176. Поселок Славышено в настоящее время расположен в Козельском районе Калужской области.

${ }^{31}$ Власьев Г. А. Потомство Рюрика... С. 54.

32 РГАДА. Ф. 1209. Оп. 4. Д. 5431. Л. 443-472 об.
}

Н. Ю. Болотина, доказывая родство княгини Марьи Долгоруковой с князьями Трубецкими, опирается на поступную крепость от Трубецких на земли в Лебедянском уезде ${ }^{33}$. Эти земли не упоминаются в Ведомости, составленной Вотчинной коллегией. Однако, в реестре конфискованных бумаг содержатся следующие документы: два договорных письма Ивана и Юрья Юрьевичей Трубецких касимовскому царевичу Семену Васильевичу, письмо о передаче лебедянских вотчин Семену Васильевичу, роспись о принятии вотчины служителем царевича С. Поляковым, и поступные на лебедянскую деревню от Трубецких княгине Марье Юрьевне, от нее князю Якову Федоровичу, от него, в свою очередь, к князю Василию Лукичу ${ }^{34}$.

Таким образом, село Спасское Лебедянского уезда является тем самым приданным, которые было передано сначала касимовскому царевичу, затем после его смерти в 1691 г., когда княгиня Марья Юрьевна осталась вдовой, по-видимому, принадлежало ей вместе с землями умершего мужа и в 1705 г. перешли к князю Долгорукову.

На имения князя В. Л. Долгорукова в Московском уезде было составлено несколько отписных книг.

12-14 августа была составлена отписная на имение в Монатьином, Быковом и Коровином стане: село Сретенское, деревни Подушкину, Пятино, Чернцово ${ }^{35}$.

Село Сретенское (Неклюдово) ${ }^{36}$ В. Л. Долгоруков приобрел у своего двоюродного брата С. Г. Долгорукова (ум. 1739) 19 декабря 1727 г. К этому же селу прилагалась деревня Чернцова с пустошами.

Деревня Пятинино, которая описывалась вместе с Неклюдовым и Чернцовым, появилась у В. Л. Долгорукова, вероятно, позже 1727 г. В сведениях Вотчинной коллегии она не называется. И действительно, в реестре бумаг, конфискованных у В. Л. Долгорукова, была описана купчая от А. П. Волынского на деревню Петино (Пятинино) $)^{37}$; она находится в делах Комиссии и датируется 14 июня 1728 г. ${ }^{38}$

\footnotetext{
${ }^{33}$ Болотина Н. Ю. «И ныне писал ко мне он, муж мой, из Копенгагена». Княгиня М.Ю. Долгорукова при датском дворе. 1708-1711 гг // Исторический архив. М., 2010. №. 1. С. 181.

${ }^{34}$ Ф. 1239. Оп. 2. Д. 1734. Л. 368 об. - 369 об.

${ }_{35}^{35}$ РГАДА. Ф. 1209. Оп. 4. Д. 5430. Л. 277-288об.

36 Близ пос. Нагорный Мытищинского района Московской области.

${ }^{37}$ РГАДА. Ф. 1239. Оп. 2. Д. 1734. Л. 375.

${ }^{38}$ Там же. Д. 1737. Л. 212.
} 
Деревню Подушкино В. Л. Долгоруков купил у А. Л. и И. Л. Нарышкиных 16 декабря 1729 г. Купчая сохранилась в фонде Комиссии ${ }^{39}$.

Канцеляристом И. Крапивиным 14-25 августа была сделана опись имений в Молоцком стане: сел Коледино, Ивино и деревни Шипчиной ${ }^{40}$.

Село Коледино, по данным Вотчинной коллегии, В. Л. Долгоруков выменял в 1704 г. у стольника Якова Хрущова ${ }^{41}$. Село Ивино вошло в состав земель князя в 1714 г. «по даче родовой вотчины деда ево». Вероятно, вместе с селом Ивиным от И. А. Желябужского В. Л. Долгоруков получил деревню Прислониху в Кинешемском уезде. В отписной книге происхождение этих вотчин не упоминается.

Земли села Знаменского-Буртас, Никольского-Куземкина и деревни Самарихи Керенского уезда были описаны в сентябре 1730 г. ${ }^{42}$, то есть уже после того, как сосланный в село Знаменское В. Л. Долгоруков был отправлен в Соловецкий монастырь.

В отписной книге есть сведения о происхождении этих земель. В 1705 г. В. Л. Долгоруков выменял у 9 человек в урочищах 450 четвертей. Также в отписной книге указывается, что у Василья Тенищева в урочищах речки Буртас В. Л. Долгоруков выменял 25 четвертей. Часть земель он получил в наследство от своего дяди Я. Ф. Долгорукова (1639-1720): 1000 четвертей пашни и 15000 копен сенных покосов.

В 1729 г. В. Л. Долгоруков купил у керенских помещиков И. Е. Богданова «с товарыщи» 200 четвертей в «диком поле». Реестр с упоминанием этих документов есть в делах Комиссии по описи пожитков князей Долгоруковых ${ }^{43}$, там же сохранились копии некоторых купчих ${ }^{44}$.

Таким образом, В. Л. Долгоруков значительно расширил свое владение в Керенском уезде за счет земель «дикого поля».

На примере этой отписной книги хорошо видно, что у Вотчинной коллегии сведения о составе земель были далеко не полны. В Ведомости, составленной Вотчинной коллегией, эти земли не упоминаются вообще.

\footnotetext{
${ }^{39}$ Там же. Л. 213 об.

40 Там же. Оп. 4. Д. 5430. Л. 289-299.

${ }^{41}$ Там же. Ф. 1239. Оп. 4. Д. 5419. Л. 79.

42 Там же. Ф. 1209. Оп. 4. Д. 5430. Л. 369 - 451. Ныне все три

- в Башмаковском районе Пензенской области.

${ }^{43}$ РГАДА. Ф. 1239. Оп. 2. Д. 1731. Л. 285-286.

${ }^{44}$ Купчие грамоты от 18 и 21 февраля 1729 г. с И. Е. Богдановым и Р. Е. Богдановым: Там же. Д. 1737. Л. 214-214 об.
}

27 июля 1730 г. канцеляристом И. Дмитриевым была составлена отписная книга на села Ерахтура, деревню Шишкино, село Мышицы, деревни Малые Пексели, Большие Пексели, Куземкино, село Беляково с принадлежащей к нему деревней Власово в Касимовском уезде $\mathrm{e}^{45}$.

Согласно сведениям Вотчинной коллегии, В. Л. Долгоруков получил эти обширные земли в 1707 г. за свою службу из поместья касимовского царевича Симиона Васильевича. А в 1708 г. В. Л. Долгоруков получил еще одну часть поместья в селе Мышицах. В 1707 г. В. Л. Долгоруков вернулся из Польши и в сентябре этого же года был отправлен послом в Данию.

Однако, данные Вотчинной коллегии не совпадают с данными отписных книг по количеству земель - в Ведомости написано, что в этих землях $2247+85$ четвертей земли, тогда как в итоговой записи в отписной книге в селе Ерахтура с деревнями значится 2507 четвертей земли. Эта цифра также вызывает сомнения, так как при обыкновенном сложении четвертей земли в каждой деревне (сведения в той же отписной) получается около 2554 четвертей.

По справке из Вотчинной коллегии в 1707 г. село Беляково и деревню Власово (Власовскую) князь получил в приданное от своей жены Авдотьи, сестры касимовского царевича Симиона. Однако, в 1730 г. В. Л. Долгоруков был женат на Марье - в реестре конфискованных бумаг находится ее завещание ${ }^{46}$. Н. Ю. Болотиной было высказано предположение, что княгиня Марья, урожденная Трубецкая, была замужем за В. Л. Долгоруковым с 1705 г. ${ }^{47}$

Вероятнее всего, писцы Вотчинной коллегии допустили ошибку, так как Авдотьей звали жену Александра Лукича, брата В.Л. Долгорукова. Каким образом урожденная княгиня Трубецкая получила в приданное земли Касимовского уезда? Это объясняет один из документов, описанных в реестре конфискованных бумаг: «Письмо от касимовского царевича Ивана Васильевича, что он дал брата своего царевича Симеоновои жене княгине вдове Марье Юрьевне о невзыскании взятых денег братом ево за пошехонские вотчины, деревню Руновскую з деревнями,

\footnotetext{
${ }^{45}$ Там же. Оп. 4. Д. 5430. Л. 455 - 553. Ныне эти населенные пункты расположены в Шиловском районе Рязанской области.

${ }^{46}$ РГАДА. Ф. 1239. ОП. 2. Д. 1734. Л. 345.

${ }^{47}$ Болотина Н. Ю. «И ныне писал...» С. 179 - 199.
} 


\section{Политика и общество 2 (110) • 2014}

две тысячи пятьсот рублев, 7200-го году» ${ }^{48}$. То есть княгиня Марья Юрьевна первый раз была замужем за касимовским царевичем Симеоном, и к 1692 г. стала вдовой. Второй раз княгиня вышла замуж за В. Л. Долгорукова не позднее 1705 г. и в приданное получила земли своего первого мужа.

В 1762 г., когда Кабинетом министров были запрошены сведения из Дворцового архива об оставшихся «за роздачами» землями князей Долгоруких, на имение В. Л. Долгорукова была составлена ведомость. В ней указывалось, что половина села Беляково Елатомского уезда перешла из земель касимовского царевича из поместья в вотчину. Но никаких подробностей не приводилось ${ }^{49}$.

$\mathrm{B}$ «Ведомости» при описании половины села Белякова и села Власово указано, что они относятся к городу Елатьма. В колонке, предназначенной для цитаты из отписных книг, написано, что отписных книг на эти земли подано не было. Это представляется странным, так как села и деревни Касимовского уезда отписывал один писец - канцелярист Иван Дмитриев и на них была составлена одна отписная книга. Более того, в отписных книгах и в справке совпадают сведения относительно количества четвертей земли - такое совпадение более чем удивительно, при условии, что отписные книги в большинстве случаев показывают иные, нежели Вотчинная коллегия, данные о количестве четвертей.

По данным отписной книги со времен переписи 1710 г., на которую ссылаются местные старосты, сильно изменилось количество населения. По переписи 1710 г. было 133 двора, к моменту описи 1730 г. 225 дворов, то есть, за 20 лет прибавилось 92 двора.

28 августа 1730 г. были отписано имение Долгорукова в Кромском уезде в Речицком стане - село Ефратово $^{50}$. Относительно происхождения этих земель в отписной книге нет упоминания, кроме того, что это «отца ево вотчина». На месте же отписчик выяснил, что помимо тех сведений, что имеются в Вотчинной коллегии «во 195-м году отец его стольник князь Лука княж Федоров сын Долгоруков выменил» у С. К. Алехина, Я. И. Богучарова, Л. О. Сбитова, И. Г. Анпилогова, С. Т. и О. С. Картамышевых 300 четвертей дикого поля. В отписной книге есть указание, что этими угодья-

\footnotetext{
${ }^{48}$ РГАДА. Ф. 1239. Оп. 2. Д. 1734. Л. 361.

49 Там же. Оп. 3. Д. 30709. Л. 3 об.

${ }^{50}$ Там же. Оп. 4. Д. 5431. Л. $148-161$.
}

ми на момент отписки владели крестьяне Ю. Ю. Трубецкого, но нет никаких данных о том, как эти земли к ним перешли. В Ведомости Вотчинной коллегии эти земли не упоминаются вовсе. Согласно предположению Н. Ю. Болотиной, князь Ю. Ю. Трубецкой - родной брат княгини Марьи Долгоруковой ${ }^{51}$. Вероятно, эти земли В. Л. Долгоруков передал на каких-то условиях своему шурину.

В справке из Вотчинной коллегии не содержится сведений о землях В. Л. Долгорукова в Копорском, Оболенском и Рузском уездах, несмотря на то, что отписные книги на эти имения были поданы. В отписных книгах нет сведений о происхождении этих земель в составе вотчин князя. В Оболенском уезде ему принадлежала родовая вотчина село Покровское Тинково, которое было отписано 31 августа 1730 г. ${ }^{52} \mathrm{~B}$ реестре бумаг, конфискованных у В. Л. Долгорукова, также упоминается комплекс документов на земли Оболенского уезда:

«Купчая князь Ивана Ивановича Долгорукова на полчетверти села Никольского, на деревню Шопину». И. И. Долгоруков родился в 1680 г., он приходился троюродным братом В. Л. Долгорукову. После смерти отца Ивана Дмитриевича Долгорукова в 1691 г. получил довольно большие земельные наделы, владел землями в Оболенском уезде ${ }^{53}$. Умер через три дня после жены Аграфены Лукиничны Ляпуновой, 19 января 1737 г.

«Купчая от дьяка Феодосея Семенова сына Манукова на село Никольское и деревню Шопину».

«Зделочная запись на землю от князь Юрья Щербатова» ${ }^{54}$.

Земли в Оболенском уезде являются родовой вотчиной оболенских князей и происходящих от них Долгоруковых. Вероятно, В. Л. Долгоруков получил часть этих земель по наследству от отца в 1710 г., однако, в делах «Комиссии по описи пожитков» никаких документов, это подтверждающих, обнаружено не было.

Также нет сведений в Ведомости о землях в Рузском уезде. Из отписной книги также неясно их происхождение 5 . В реестре конфискованных бумаг есть копии с грамот, с купчих на крестьян и «закладная

\footnotetext{
${ }^{51}$ Болотина Н.Ю. «И ныне писал...» С. 179 - 199.

52 РГАДА. Ф. 1209. Оп. 4. Д. 5431. Л. 576-584 об.

${ }_{53}^{53}$ Власьев Г.А. Потомство Рюрика... С. 72-73.

${ }_{54}$ РГАДА. Ф. 1239. Оп. 2. Д. 1734. Л. 374.

${ }^{55}$ Там же. Оп. 4. Д. 5431 . Л. 30 - 37.
} 
на Рузскую вотчину от князя Андрея Борисова сына Долгорукова» ${ }^{56}$. Возможно, именно этим и объясняется происхождение этих земель в составе вотчины В. Л. Долгорукова. Однако, ни в одном из документов нет дат. Г. А. Власьев приводит сведения, о том, что в 1713 г. село Корманово Рузского уезда отошло к В. Л. Долгорукову по закладной. А. Б. Долгоруков, двоюродный брат В. Л. Долгорукова, умер в 1712 г., в тот же год, когда его послали на учебу в Голландию ${ }^{57}$.

В Курском уезде в Усожском стане 5 сентября 1730 г. были отписаны земли в деревне Гнездилово и в селе Игине ${ }^{58}$. Согласно сведениям Вотчинной коллегии в 1724 г. у вдовы Ирины Исаковой В. Л. Долгоруков купил одного человека, и еще одного человека ему продала Марья Бизяева. В 1727 г. он же купил у курского помещика Я. Галактионова 6 душ крестьян. Однако, все они на момент отписки были записаны за А. Г. Долгоруковым, а отписанные 34 четверти земли в Курском уезде - пусты. Как и когда эти земли вошли в состав вотчин В. Л. Долгорукова, сведений нет ни в отписной книге, ни в «ведомости», составленной в Вотчинной коллегии.

В Копорском уезде В. Л. Долгоруков владел Ритинской мызой, которую отписал капрал Алексей Зборовский при отписке его петербургских домов ${ }^{59}$. На Ритинскую мызу в реестре бумаг В.Л. Долгорукова находится только один документ - выпись из отказной книги Ритинской мызы ${ }^{60}$. Очевидно, что имение в Копорском уезде В. Л. Долгоруков мог получить после 1703 г., когда его территория была отвоевана у Швеции.

Таким образом, по собранным сведениям известно, что В. Л. Долгоруков владел землями в 13 уездах (см. таблицу 1). Все они были отписаны в дворцовое ведомство в сентябре 1730 г. Осталась невыявленной только одна отписная книга - на село Иванково Алатырского уезда.

В таблице 1 сведения о составе вотчин В. Л. Долгорукова имеют следующие количественные характеристики: дворы помещика, количество душ мужского и женского пола среди дворовых, крестьянские дворы, количество душ мужского и женского пола среди крестьян, сведения о размере пашенной земли, покосов.

В большинстве случаев отписчик в конце книги подводил итог, на основе которого и составлена данная таблица. Однако, в некоторых отписных книгах, по невыясненным причинам этого произведено не было, в таком случае соответствующая графа остается незаполненной. В нескольких «незавершенных книгах» есть отметки на полях, соответствующие началу описания нового двора - тогда дворы были посчитаны вручную и сведения о количестве дворов были представлены в таблице.

Таблица 1 Состав вотчин князя В. Л. Долгорукова

\begin{tabular}{|c|c|c|c|c|c|c|c|c|}
\hline дв. пом. & $\begin{array}{c}\text { душ дв. } \\
\text { м.п. }\end{array}$ & $\begin{array}{c}\text { душ дв. } \\
\text { ж.п. }\end{array}$ & дв. кр. & $\begin{array}{c}\text { душ м.п. } \\
\text { кр. }\end{array}$ & $\begin{array}{c}\text { душ ж.п. } \\
\text { кр. }\end{array}$ & $\begin{array}{c}\text { всего } \\
\text { душ }\end{array}$ & $\begin{array}{c}\text { пашни в } \\
\text { 1-м поле, } \\
\text { четв. }\end{array}$ & $\begin{array}{c}\text { покосы, } \\
\text { копен }\end{array}$ \\
\hline \multicolumn{9}{|c|}{ Алаторский у. ${ }^{1}$} \\
\hline \multicolumn{9}{|c|}{ с. Иванково } \\
\hline & & & 37 & 102 & 121 & & & \\
\hline \multicolumn{9}{|c|}{ Касимовский у. ${ }^{2}$} \\
\hline 1 & & & 225 & 1698 & 1607 & 3305 & 2507 & 3050 \\
\hline \multicolumn{9}{|c|}{ с. Ерахтура } \\
\hline 1 & & & 97 & 806 & 766 & 1572 & 1200 & 1000 \\
\hline \multicolumn{9}{|c|}{ д. Шишикино } \\
\hline & & & 2 & 27 & 29 & 56 & 100 & 55 \\
\hline
\end{tabular}

\footnotetext{
${ }^{56}$ Там же. Ф. 1239. Оп. 2. Д. 1734. Л. 372 об.

${ }^{57}$ Власьев Г. А. Потомство Рюрика... С. 55.

${ }^{58}$ РГАДА. Ф. 1209. Оп. 4. Д. 5431. Л. 230-233 об.

${ }^{59}$ Там же. Ф. 1239. Оп. 2. Д. 1732. Л. 38 - 51 об.
}

${ }^{60}$ Там же. Д. 1734. Л. 370 об. 


\section{Политика и общество 2 (110) • 2014}

с. Мышица на рч. Мыцевне

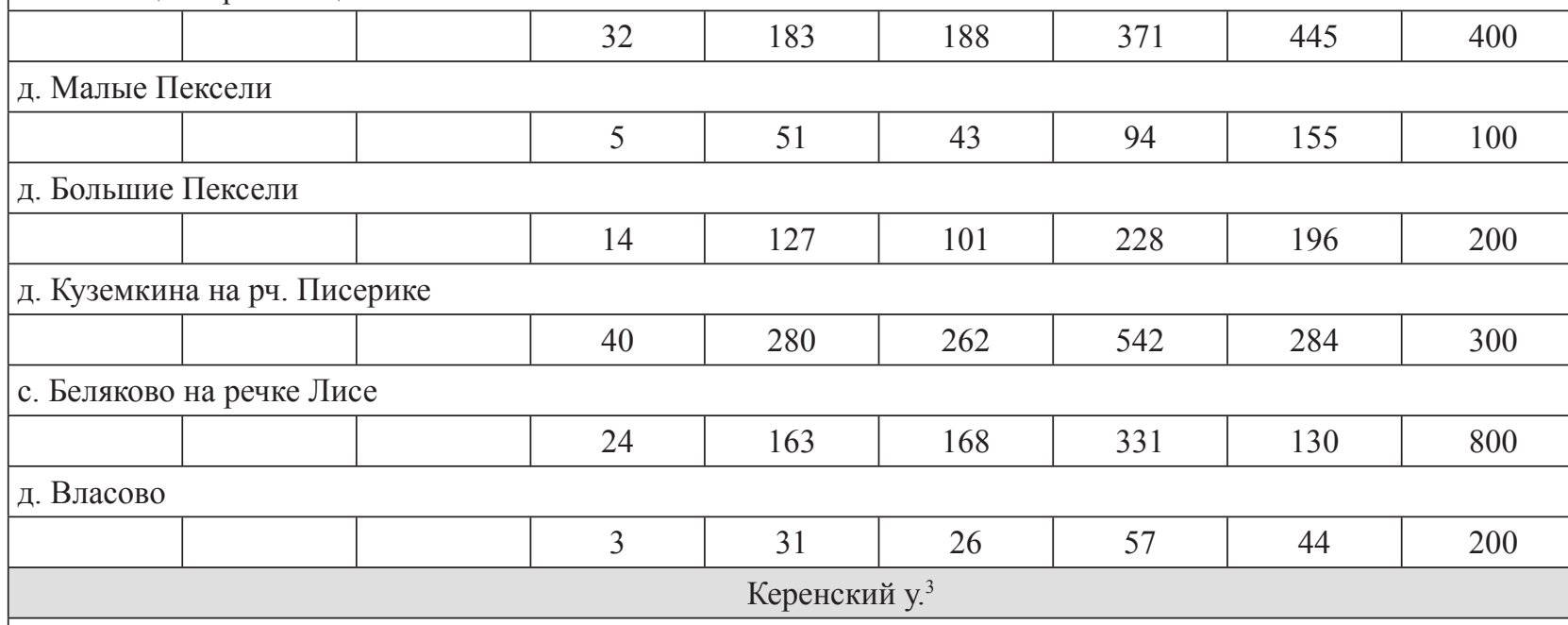

с. Знаменское-Буртас

\begin{tabular}{|c|c|c|c|c|c|c|c|c|}
\hline 1 & 16 & 22 & 284 & 281 & $1004^{4}$ & & $1000^{5}$ & 15000 \\
\hline \multicolumn{9}{|c|}{ с. Никольское-Куземкино } \\
\hline & & & 96 & 114 & 338 & & & \\
\hline \multicolumn{9}{|c|}{ д. Самариха } \\
\hline 1 & & & 53 & 53 & 151 & & & \\
\hline \multicolumn{9}{|c|}{ Кинешемский у. ${ }^{6}$} \\
\hline \multicolumn{9}{|c|}{ д. Прислониха с дд. } \\
\hline & & & 18 & 54 & 34 & & 131 & \\
\hline \multicolumn{9}{|c|}{ д. Гриденская } \\
\hline & & & 14 & 36 & 32 & & & \\
\hline \multicolumn{9}{|c|}{ д. Блиниха } \\
\hline & & & 6 & 18 & 18 & & & \\
\hline \multicolumn{9}{|c|}{ д. Книдякова } \\
\hline & & & 14 & 50 & 50 & & & \\
\hline \multicolumn{9}{|c|}{ Козельский у. ${ }^{7}$} \\
\hline \multicolumn{9}{|c|}{ с. Ерлыково } \\
\hline 1 & 11 & 12 & 27 & 97 & 117 & & & \\
\hline \multicolumn{9}{|c|}{ сц. Кудринское Лавровское } \\
\hline 1 & 10 & 8 & 28 & 117 & 103 & & & \\
\hline \multicolumn{9}{|c|}{ сц. Славышино } \\
\hline & & & 18 & 66 & 74 & 140 & $265^{8}$ & \\
\hline \multicolumn{9}{|c|}{ с. Гришинское } \\
\hline 1 & 6 & 4 & 23 & 68 & 96 & & $50^{9}$ & \\
\hline \multicolumn{9}{|c|}{ Копорский у. ${ }^{10}$} \\
\hline \multicolumn{9}{|c|}{ Ритинская мыза } \\
\hline 1 & & & 65 & 222 & 206 & 428 & 249 & 268 дес. \\
\hline
\end{tabular}


Демография и статистика

\section{Кромский у. ${ }^{11}$}

с. Ефратово на рч. Тростенке с пус.

\begin{tabular}{|c|c|c|c|c|c|c|}
\hline 1 & & 60 & 299 & 296 & 595 & 1238 \\
\hline \multicolumn{7}{|c|}{} \\
\begin{tabular}{|l|l} 
Курский у. ${ }^{12}$ \\
д. Гнездилово
\end{tabular}
\end{tabular}

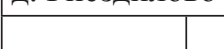

д. Игина

\begin{tabular}{l}
\hline \\
\hline \\
\hline
\end{tabular}

с. Спасское с дд., с. Парое

\begin{tabular}{|c|c|c|c|c|c|r|}
\hline 1 & & 112 & 820 & 855 & & $450+10$ \\
\hline \multicolumn{7}{|c|}{ Московский у. ${ }^{14}$} \\
д. Подушкина на рч. Вздериноге, пус. Мухино \\
д)
\end{tabular}

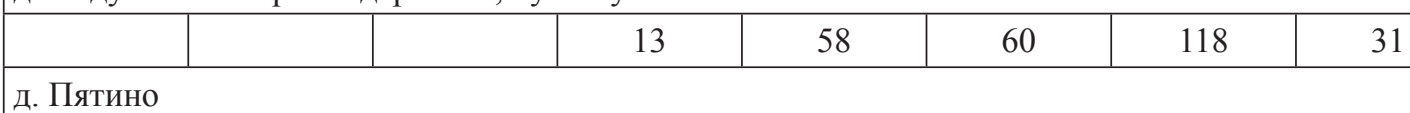

\begin{tabular}{|c|c|c|c|c|c|}
\hline \multicolumn{6}{|l|}{ Д. Пятино } \\
\hline & 1 & 3 & 3 & 6 & $106^{15}$ \\
\hline \multicolumn{6}{|l|}{ д. Ченцово } \\
\hline & 17 & 69 & 88 & 157 & \\
\hline
\end{tabular}

с. Сретенское- Неклюдово на рч. Вздериноге, пус. Микулино

\begin{tabular}{|c|r|}
\hline c. Коледино на рч. Коноплянке \\
\hline
\end{tabular}

\begin{tabular}{|c|c|c|c|c|c|c|c|c|}
\hline 1 & 2 & 3 & 7 & 25 & 23 & & $76+224$ & \\
\hline \multicolumn{9}{|c|}{ д. Шипчино на Бол. Серпуховской дороге } \\
\hline & & & 4 & 20 & 14 & & & \\
\hline \multicolumn{9}{|c|}{ сц. Ивино } \\
\hline 1 & & 5 & 7 & 41 & 44 & & 147 & \\
\hline \multicolumn{9}{|c|}{ Рузский у. ${ }^{16}$} \\
\hline \multicolumn{9}{|c|}{ с. Успенское с дд. } \\
\hline 1 & & & 55 & 283 & 275 & 558 & 637 & \\
\hline \multicolumn{9}{|c|}{ Юрьева слобода, пуст. Теплево-Зехино } \\
\hline & & & & & & & 82 & \\
\hline \multicolumn{9}{|c|}{ Оболенский у. ${ }^{17}$} \\
\hline \multicolumn{9}{|c|}{ с. Покровское-Тинково } \\
\hline 1 & 12 & 13 & 14 & & & & 469 & 430 \\
\hline \multicolumn{9}{|c|}{ д. Чаусово } \\
\hline & & & 2 & 10 & 19 & & & \\
\hline \multicolumn{9}{|c|}{ д. Сафонково } \\
\hline & & & 1 & 6 & 4 & & & \\
\hline \multicolumn{9}{|c|}{ д. Базовка } \\
\hline & & & 2 & 11 & 12 & & & \\
\hline
\end{tabular}




\section{Политика и общество 2 (110) • 2014}

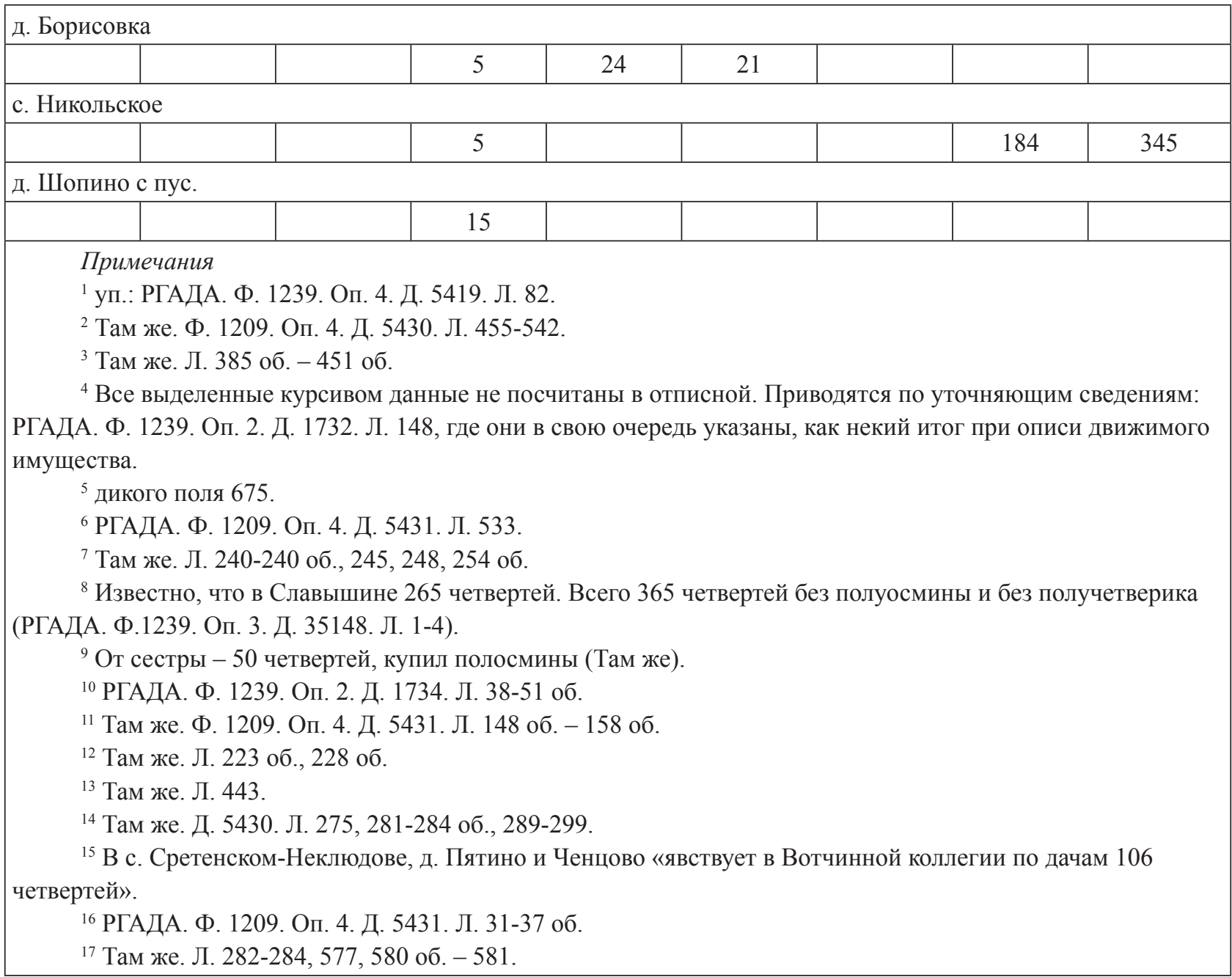

Для того чтобы проследить, насколько петровские преобразования отразились на землевладении князей Долгоруковых, необходимо изучить состав их земель в XVII-XVIII вв. По наблюдениям О. А. Шватченко, в начале XVII в. Долгоруковы не отличались от мелких вотчинников из числа уездных дворян. При этом в составе их земель сохранились небольшого размера старые родовые вотчины XV-XVI в. в Оболенском уезде ${ }^{61}$. На 16 упомянутых в писцовых книгах представителей рода Долгоруковых во время валового описания 1620-х гг. приходилось около 5000 четвертей земли в 10 уездах. Всего во владении князей находилось 25 вотчин ${ }^{62}$.

В 1620-1630-е гг. Долгоруковы имели уже сильные позиции в чиновничьей структуре аппарата управления: боярин Владимир Тимофеевич, отец первой жены

${ }^{61}$ Шватченко О. А. Светские феодальные вотчины в первой трети XVII в. М., 1990. С. 193.

62 Там же. С. 237. царя Михаила Федоровича - Марии Владимировны был крупным вотчинником. К 1646 г. землевладение князей увеличилось до 30 вотчин. О. А. Шватченко отмечает, что Долгоруковы «составляли большую группу крупных вотчинников и служили исключительно в стольниках, откуда позднее переводились сразу в бояре, что являлось отличительной особенностью служебной карьеры русской земельной аристократии» ${ }^{63}$. К 1646 г. стольники Григорий Данилович, Петр Алексеевич, Федор Богданович и Юрий Алексеевич Долгоруковы относились уже к крупным вотчинникам ${ }^{64}$.

К 1678 г. землевладение Долгоруковых значительно увеличилось - до 82 вотчин. Дворовладение выросло в 8 раз, душевладение в 11 раз. Дол-

${ }^{63}$ Шватченко О. А. Светские феодальные вотчины во второй половине XVII в. (историко-географический очерк). М., 1996. C. 122.

${ }^{64}$ Там же. С. 112. 
горуковы сохранили старые родовые вотчины в Белевском, Дмитровском, Каширском, Московском и Оболенском уездах. Новые вотчины образовывались в местах испомещения - в Алексинском, Бежецком, Верейском, Владимирском, Вологодском, Звенигородском, Кромском, Козельском, Тульском и Шацком уездах ${ }^{65}$. В 1678 г. Владимир Дмитриевич и Юрий Алексеевич были боярами, Борис Федорович, Иван Дмитриевич, Лука Федорович, Прохор Григорьевич, Федор Алексеевич и Федор Богданович - стольниками ${ }^{66}$.

Во время петровских описаний 1705 и 1711 гг. в собственности Долгоруковых было 86 вотчин. Князь Василий Лукич владел следующими землями ${ }^{67}$ : Козельский уезд, Рузский стан, сельцо Ерлыково; Лебедянский уезд, Окологородный стан, село Спасское; Московский уезд, Замыцкий стан, село Улино, Ивино тож; Московский уезд, Молоцкий стан, село Коледино; Оболенский уезд село Покровское; Рузский уезд, Вышковской стан, село Корманово.
В отписных книгах практически никогда не указывалось, каким образом лицо, подвергшееся конфискации, получило то или иное владение. Эти сведения были нужны только если встречались какие-то сложности при отписке. Основным документом для уточнения происхождения различных земель послужила справка из Вотчинной коллегии. В случае, если в этой справке сведения не указаны, приходилось обращаться к реестру конфискованных бумаг. Но поскольку в нем документы переписаны без даты, происхождение некоторых земель осталось неизвестным, к примеру, вотчины в Копорском уезде. Стоит отметить, что представленные ниже подсчеты не до конца полны: в источниках нет данных о дате вхождения в состав вотчин В. Л. Долгорукова земель в Копорском и Курском уездах, фрагментарны сведения о землях в Керенском и Московском уездах.

Земельные наделы поступали к Долгорукову разными путями: 10 вотчин были получены в результате сделки покупки или обмена, 11 было получено от родственников, и всего 1 вотчина была пожалована за службу.

Таблища 2. Происхождение вотчин князя В. Л. Долгорукова

\begin{tabular}{|l|l|l|l|}
\hline \multicolumn{1}{|c|}{ Гор } & \multicolumn{1}{|c|}{ Вотчина } & \multicolumn{1}{|c|}{ Происхождение } \\
\hline 1 & 1684 & Кинишемский уезд в деревне Хоромне & Купля \\
\hline 2 & 1697 & Кинишемский уезд пустошь Когрята & Купля \\
\hline 3 & 1697 & $\begin{array}{l}\text { Козельский уезд сельцо Славышино, Кудринское, село } \\
\text { Ерлыково }\end{array}$ & Наследство от деда \\
\hline 4 & 1700 & Алатырский уезд село Иванково & Наследство от отца \\
\hline 5 & После 1703 г. & Копорский уезд Ритинская мыза & Вероятно пожалование \\
\hline 6 & 1704 & Козельский уезд в селе Гришинском & Купля \\
\hline 7 & 1704 & Лебедянский уезд в селе Парое & Обмен \\
\hline 8 & 1704 & Московский уезд село Коледино & Обмен \\
\hline 9 & 1705 & Керенский уезд в урочищах & Обмен \\
\hline 10 & 1705 & Козельский уезд в селе Гришинском & Наследство от сестры \\
\hline 11 & 1705 & Лебедянский уезд село Спасское & Приданное \\
\hline 12 & 1707 & Касимовский уезд село Ерахтур с деревнями & Пожалование \\
\hline 13 & 1707 & Касимовский уезд село Беляково, деревня Власово & Приданное \\
\hline
\end{tabular}

65 Там же. С. 122.

66 Там же. С. 113.

${ }^{67}$ Там же. С. 148-149. 


\section{Политика и общество 2 (110) • 2014}

\begin{tabular}{|c|c|c|c|}
\hline 14 & 1710 г. & Оболенский уезд село Покровское Тинково & Наследство от отца \\
\hline 15 & 1710 г. & Кромский уезд село Ефратово & Наследство от отца \\
\hline 16 & 1713 & Рузский уезд село Корманово & $\begin{array}{l}\text { По закладной от троюродного } \\
\text { брата }\end{array}$ \\
\hline 17 & 1714 & Кинишемский уезд деревня Прислониха & Наследство от деда \\
\hline 18 & 1714 & Московский уезд село Ивино & Наследство от деда \\
\hline 19 & $\begin{array}{l}\text { не позднее } \\
1720 \text { г. }\end{array}$ & $\begin{array}{l}\text { Керенский уезд (села Знаменское, Никольское, деревня } \\
\text { Самариха) }\end{array}$ & Наследство от дяди \\
\hline 20 & 1727 & Московский уезд село Сретенское (Неклюдово) & Купля \\
\hline 21 & 1728 & Московский уезд деревня Пятинино & Купля \\
\hline 22 & 1729 & Московский уезд деревня Подушкино & Купля \\
\hline 23 & 1729 & Керенский уезд в диком поле & Купля \\
\hline 24 & б.д. & Курский уезд в деревне Гнездилово, селе Игине & Возможно купля \\
\hline
\end{tabular}

Вотчина В. Л. Долгорукова формировалась не единовременно, можно выделить несколько хронологических периодов. Первый приходится на 1684-1708 гг. в этот период Долгорукову тем или иным путем стали принадлежать 13 его вотчин. При этом по описаниям 1705 и 1711 г. за В. Л. Долгоруковым записано всего 6 вотчин. Отписные книги не содержат никаких иных сведений о динамике - продажах или покупках вотчин в этот период времени - то есть все земли, приобретенные в этот период В. Л. Долгоруковым, просуществовали в составе его земель до отписки в казну в 1730 г. То есть на момент составления ландратских книг 1705 и 1711 гг. указанные земли принадлежали Долгорукову, но сами книги на эти вотчины не сохранились, или по каким-то причинам не были составлены.

Второй период начинается в год смерти Луки Федоровича Долгорукова (1710). Василий Лукич получил тогда вотчины в Кромском уезде, обозначенные в ведомости как «отца ево вотчина», и родовые вотчины в Оболенском уезде.

В 1713 г. по закладной в связи со смертью троюродного брата А. Б. Долгорукова получил земли в Рузском уезде.

В 1714 г. князь получил в наследство от деда И. А. Желябужского деревню Прислониху в Кинишемском уезде, и в Московском уезде село Ивино.

Не ранее 1720 г. В. Л. Долгоруков получил в наследство от своего дяди Я. Ф. Долгорукова земли в Керенском уезде. Ни в отписной книге, ни в «Ведомости», эти вотчины поименно не называются. Так как остальные приобретения князя в этом уезде - это покупка земель «дикого поля», а в 1730 г. В. Л. Долгоруков владел селами Знаменским, Никольским и деревней Самарихой, можно предположить, что именно их он получил в наследство от дяди.

В этот период Долгоруков не совершал никаких сделок по покупке или обмену вотчин. В промежуток с 1710 по 1720 г. приращение вотчины происходило за счет родственников: получение наследства от отца, дяди и деда, а также в счет долга от троюродного брата.

Третий период приходится на 1727-1729-е гг. - в это время он купил четыре вотчины. Большая часть покупок была сделана в Московском уезде - деревни Сретенское (Неклюдово), деревня Пятинино и деревня Подушкино. Также В. Л. Долгоруков купил 675 четвертей в диком поле Керенского уезда. На этот период приходится активное продвижение по службе - в 1728 г. В. Л. Долгоруков был назначен членом Верховного тайного совета. Однако, такое повышение существенно не отразилось на его земельных владениях - за эти годы не произошло резкого увеличения состава вотчин.

Таким образом, в складывании комплекса вотчинных земель В. Л. Долгорукова выделяется довольно значимый период с 1708 по 1727 г., когда он не совершал сделок по покупке или обмену вотчин, которые просуществовали бы в его собственности хоть сколько-нибудь значимый период времени. Это может быть связано с особенностями дипломатической службы В. Л. Долгорукова, так как 
в этот период он практически не находился в России. В 1707 г. Долгоруков был командирован с посольством в Данию, где пробыл до 1720 г. В 1720 г. был отозван и послан во Францию, где находился вплоть до 1722 г. В 1723 г. В. Л. Долгоруков вернулся в Россию. В 1724-1727 гг. Долгоруков находился в Варшаве, кратковременно возвращаясь в Россию. С 1728 г. он находился в России безвыездно ${ }^{68}$.

Примечательно, что за свои службы дипломат получал, вероятно, какие-то иные награды, нежели земли. Единственное пожалование из поместья касимовского царевича было сделано в 1707 г. и, вероятно, связано с карьерными успехами В. Л. Долгорукова и завершением его миссии в Польше. Земли в Касимовском уезде составляли существенную долю среди всех остальных вотчин: по данным отписных книг 225 крестьянских дворов и около 2500 четвертей земли. По количеству дворов эта вотчина уступает только Керенским деревням.

Следует отметить нерешенные вопросы в истории формирования некоторых вотчин. В некоторых уделах В. Л. Долгоруков приобретал сначала небольшой надел земли (к примеру, 10 четвертей в селе Парое Лебедянского уезда), а по прошествии времени получал от родственников в этом же уезде большое владение. На данном этапе достаточно убедительно объяснить причины подобных действий непросто. Вероятно, князья Долгоруковы стремились приобретать земли в непосредственной близости друг от друга. Более точный ответ на этот вопрос можно получить, перенеся на карту сведения о землях В. Л. Долгорукова и сравнив их с земельными наделами иных представителей рода - такую возможность могут дать отписные книги: земли Долгоруковых отписывались вместе и иногда вотчины разных князей отписывал один и тот же человек ${ }^{69}$.

${ }^{68}$ Корсакова В. Долгоруков (Долгорукий), князь Василий Лукич // Русский биографический словарь. СПб., 1905. Т. 6. С. 511-522; Именной указатель / Сост. М. А. Новикова // Соловьев С.М. Соч.: В 18 т. / Под. ред. И. Д. Ковальченко. М., 1993. Т. 10. С. 724; Бантыш-Каменский Д. Н. Словарь достопамятных людей Русской земли. М., 1836. Ч. 2. С. 257272; Макарий, еп. Последние дни кн. В. Л. Долгорукова в Соловецком монастыре. // ЧОИДР. 1880. Т. 3. С. 19-32; Корсаков Д. А. Из жизни русских деятелей XVIII века. Казань, 1891. С. 194-218.

${ }^{69}$ К примеру, канцелярист Иван Крапивин отписывал подмосковные земли князей А. Г. Долгорукова и В. Л. Долгорукова, что может служить косвенным свидетельством их географической близости. РГАДА. Ф. 1209. Оп. 4. Д. 5430. Л. 272-273; Ф. 1209. Оп. 4. Д. 5430. Л. 277 - 288 об.
Таким образом, на основе отписных книг удалось не только определить состав вотчин В. Л. Долгорукова на момент конфискации имущества, но и провести исследование динамики формирования вотчинного комплекса. Для максимально полной реконструкции процесса формирования этого комплекса были привлечены сведения семейной и карьерной биографии князя. Отписные книги в качестве источника по истории светского землевладения в период дворцовых переворотов очень неоднородны по своему составу и содержанию и сложны для интерпретации. Для того, чтобы целостно представить этот источник в свете исследуемой проблемы необходимо привлекать многочисленные иные источники - в этом заключается основная сложность работы с отписными книгами. Однако, для изучения светского землевладения XVIII в. отписные книги в совокупности с иными документами конфискации являются приоритетным и необходимым источником.

\section{Библиография:}

1. Алефиренко П. К. Отписная ведомость Канцелярии конфискации как источник по истории помещичьего землевладения // Вопросы социально-экономической истории и источниковедения периода феодализма в России Сб. ст. 70-летию А. А. Новосельского / отв. ред. Н. В. Устюгов. М., 1961. С. 307-309.

2. Богданов А. П., Каган М.Д. Желябужский Иван // Словарь книжников и книжности древней Руси. XVII в. СПб., 1992. Вып. 3. Ч. 1. С. 322-326.

3. Болотина Н. Ю. «И ныне писал ко мне он, муж мой, из Копенгагена». Княгиня М. Ю. Долгорукова при датском дворе. 1708-1711 гг // Исторический архив. М., 2010. №. 1. С. 178-198.

4. Власьев Г. А. Потомство Рюрика: Материалы для составления родословий. СПб., 1907. Т. 1. Князья Черниговские. Ч. 3.

5. Водарский Я. Е. Население России в конце XVII начале XVIII в. М., 1977;

6. Он же. Дворянское землевладение XVII - первой половине XVIII в. М., 1988.

7. Заозерский А. И. Фельдмаршал Б. П. Шереметев. М., 1989.

8. Индова Е. И. Дворцовое хозяйство в России (первая половина XVIII века). М., 1964.

9. Курукин И. В. Повседневная жизнь Тайной канцелярии. М., 2008. 


\section{Политика и общество 2 (110) • 2014}

10. Новосельский А. А. Вотчинник и его хозяйство в XVII в. М.; Л., 1929.

11. Рождественский С. В. Служилое землевладение в Московском государстве. СПб., 1897.

12. Сивков К. В. Отписные книги начала XVIII века как исторический источник // Проблемы источниковедения / под. ред. С. Н. Валка. М.-Л., 1940. С. 369-390.

13. Троицкий С. М. Районирование форм феодальной ренты в крупной вотчине России в первой четверти XVIII в. // Ежегодник по аграрной истории Восточной Европы. 1968. Л., 1972. С. 115-126;

14. Он же. Хозяйство крупного сановника России в первой четверти XVIII в. // Россия в период реформ Петра I. М., 1973.

15. Черникова Т. В. «Государево слово и дело» во времена Анны Иоанновны. // История СССР. 1989. № 5. С. 155-163.

16. Шватченко О. А. Вотчинное землевладение в России в конце XVI века. М., 2008;

17. Он же. Светские феодальные вотчины России в первой трети XVII века. М., 1990;

18. Он же. Светские феодальные вотчины России во второй половине XVII в. М., 1996;

19. Он же. Эволюция светских феодальных вотчин в России в конце XVI - начале XVIII в. Автореферат диссертации на соискание ученой степени доктора исторических наук. М., 1997;

20. Он же. Светские феодальные вотчины России в эпоху Петра I. M., 2002. http://printed.e-notabene. ru/img/save.pn

\section{References (transliteration):}

1. Alefirenko P. K. Otpisnaya vedomost' Kantselyarii konfiskatsii kak istochnik po istorii pomeshchich'ego zemlevladeniya // Voprosy sotsial'no-ekonomicheskoi istorii $\mathrm{i}$ istochnikovedeniya perioda feodalizma $\mathrm{v}$ Rossii Sb. st. 70-letiyu A. A. Novosel'skogo / otv. red. N. V. Ustyugov. M., 1961. S. 307-309.

2. Bogdanov A. P., Kagan M.D. Zhelyabuzhskii Ivan // Slovar' knizhnikov i knizhnosti drevnei Rusi. XVII v. SPb., 1992. Vyp. 3. Ch. 1. S. 322-326.

3. Bolotina N. Yu. «I nyne pisal ko mne on, muzh moi, iz Kopengagena». Knyaginya M. Yu. Dolgoruko- va pri datskom dvore. 1708-1711 gg // Istoricheskii arkhiv. M., 2010. №. 1. S. 178-198.

4. Vlas'ev G. A. Potomstvo Ryurika: Materialy dlya sostavleniya rodoslovii. SPb., 1907. T. 1. Knyaz'ya Chernigovskie. Ch. 3.

5. Vodarskii Ya. E. Naselenie Rossii v kontse XVII nachale XVIII v. M., 1977;

6. On zhe. Dvoryanskoe zemlevladenie XVII - pervoi polovine XVIII v. M., 1988.

7. Zaozerskii A. I. Fel'dmarshal B. P. Sheremetev. M., 1989.

8. Indova E. I. Dvortsovoe khozyaistvo v Rossii (pervaya polovina XVIII veka). M., 1964.

9. Kurukin I. V. Povsednevnaya zhizn' Tainoi kantselyarii. M., 2008.

10. Novosel'skii A. A. Votchinnik i ego khozyaistvo v XVII v. M.; L., 1929.

11. Rozhdestvenskii S. V. Sluzhiloe zemlevladenie v Moskovskom gosudarstve. SPb., 1897.

12. Sivkov K. V. Otpisnye knigi nachala XVIII veka kak istoricheskii istochnik // Problemy istochnikovedeniya / pod. red. S. N. Valka. M.-L., 1940. S. 369-390.

13. Troitskii S. M. Raionirovanie form feodal'noi renty v krupnoi votchine Rossii v pervoi chetverti XVIII v. // Ezhegodnik po agrarnoi istorii Vostochnoi Evropy. 1968. L., 1972. S. 115-126;

14. On zhe. Khozyaistvo krupnogo sanovnika Rossii v pervoi chetverti XVIII v. // Rossiya v period reform Petra I. M., 1973.

15. Chernikova T. V. «Gosudarevo slovo i delo» vo vremena Anny Ioannovny. // Istoriya SSSR. 1989. № 5. S. 155-163.

16. Shvatchenko O. A. Votchinnoe zemlevladenie v Rossii v kontse XVI veka. M., 2008;

17. On zhe. Svetskie feodal'nye votchiny Rossii v pervoi treti XVII veka. M., 1990;

18. On zhe. Svetskie feodal'nye votchiny Rossii vo vtoroi polovine XVII v. M., 1996;

19. On zhe. Evolyutsiya svetskikh feodal'nykh votchin v Rossii v kontse XVI - nachale XVIII v. Avtoreferat dissertatsii na soiskanie uchenoi stepeni doktora istoricheskikh nauk. M., 1997;

20. On zhe. Svetskie feodal'nye votchiny Rossii v epokhu Petra I. M., 2002. http://printed.e-notabene. ru/img/save.pn 